\title{
Chewing gum for extradural haemorrhage
}

Alastair Coutts

From 1984 to 1986 I had the privilege of being chief medical officer (surgery) and consultant surgeon in the Solomon Islands. The country lies in the western Pacific, south east of Papua New Guinea, and has a population of about 250000 . I was its only surgeon, based at Central Hospital, Honiara, on Guadalcanal, one of the many islands. Professionally I had to do things you won't find in any textbook, coping with what was available. This is probably the best example.

I had finished a long day in theatre and was looking forward to a beer on the verandah. Before leaving the hospital I looked into the office to check for post from home. Sure enough there were letters from my mum and sister but underneath was a telegram. It read:

Fifty five year old lady. Acute extradural haemorrhage. Ipsilateral pupil up. Unconscious flexor pain responses. Boggey haematoma over left middle meningeal area. Any chance you can come plus equipment to evacuate clot. Helena Goldie Hospital would refund fares.

Dr Bob Eason

\section{Emergency run}

Helena Goldie is in Munda, Western Province, about 400 miles from Honiara. I phoned Solair. "Any chance of a plane to Munda?" "No way mate, no landing lights," said the Australian pilot. What now? I had the brilliant idea of sending a "service message." This meant driving down to Solomon Islands Broadcasting Corporation and persuading someone to transmit a message on commercial radio saying that I had got Bob's message but could not make it and if anyone heard this could they please tell him. Could Bob get hold of me on the police radio in the morning? I didn't know that Munda lies at the foot of soaring mountains and in a radio shadow. Fortunately, however, a Roviana Solomon Islander heard the broadcast and ran 20 miles through forest and a tropical storm to tell Bob.

At 6 am I went down to the police station. Through hisses and crackles on the radio I heard Bob say, "Still alive, please come." I went back to the hospital to see Nyeri, the theatre sister, who put a Hudson's brace, perforator, and burrs in a box for the journey. When I landed at Munda aerodrome, a legacy of the US Air Force in the 1940s, Bob met me on a Honda 50 moped. I jumped on the back seat and we set off along a bumpy track to the hospital.

The patient was deeply unconscious and both pupils were dilated; she made extensor movements to pain with only her left arm and had a large swelling over the left side of her head as a result of being hit by a falling coconut. Her Glasgow coma score was about 4, but at least she had a clear airway and was breathing. It didn't take a genius or computed tomography to tell she had a probable left extradural haematoma and was coning.

"Operation," I said, and Bob agreed, but first we had to "story" with the relatives. Bob translated into Roviana: no operation-100\% chance of dying, operation-99\% chance of dying. Everyone sat round in the hospital compound deliberating. This took ages and Bob and I had a nonchalant ward round. Eventually they decided she should have surgery. Four of her brothers picked her up and we all went to the theatre- a small wooden hut.

\section{Basic surgery}

I asked for theatre togs but was told there were none: theatre gear was khaki shorts, flipflops, and recycled gloves. Fine. Bob was worried about giving her ketamine but I assured him this was a "no general anaesthetic situation." The patient was brought in and ceremoniously placed on the (wooden) table. Opposite me was a large Roviana male nurse who was chewing gum. We were sweating in the heat and he announced his name was Jesus. "That's all I need," I thought. Beside me was an obstetric tray and my high tech stuff from Honiara. Under the anglepoise lamp, with the whole of Munda staring through the windows, I made a standard approach through the left temple, incising skin, subcutaneous tissue, and galea. At the outer table I got out my perforator and burr and hit oil in the extradural space. This was great, but not the time for a formal craniotomy and I proceeded to rapid craniectomy with bone nibblers, thoughtfully provided by Nyeri, and evacuated a massive extradural haematoma.

The brain felt slack and life was good-temporarily. As soon as the clot had been evacuated the patient woke up, tried to get off the table, and promptly hit her head on the lamp, exclaiming, "The Lord be praised." She lay back and the previously quiescent middle meningeal artery started spurting everywhere. The matchstick ruse was useless since I had no view-there was no suction and the lamp had started flickering. She had recovered from head injury but was succumbing to blood loss. Bob went outside and bled the first four healthy people he saw, and she received four hot fresh units of blood almost immediately (everyone in Munda is $\mathrm{O}$ positive, he told me reassuringly).

Meanwhile I had a battle on my hands to stop the bleeding. The artery had of course disappeared down the foramen spinosum and was nowhere to be seen. Things were getting desperate. I looked at the tray. At one end was a pair of Wrigley's forceps and opposite me was Jesus with his gum. Lateral thinking intervened: "Jesus, please could I have some of your chewing gum?" "Of course," he said reaching into his shorts pocket for a fresh stick. "No, not that stuff, the stuff in your mouth," I retorted. Incredulously, he opened wide and handed me his gum. With thumb and forefinger I skilfully rammed it into the left foramen spinosum. The bleeding stopped. A cheer went up-mainly from the throng outside. The wound was closed and the patient was taken back to the ward. When we went to see her to our delight she was improving. Later I worried about dreadful infection. But Bob said he had the latest cephalosporin and metronidazole donated by New Zealand.

Six months later I saw our patient again. She had a minor right sided hand weakness but wanted the bone back in her head.

I thank Miss Shonate Coutts for typing the manuscript and Mr Derek McLaughlan for obtaining the patient's consent.
Gilbert Bain Hospital, Lerwick, Shetland ZE1 ORB Alastair Coutts, consultant surgeon agcoutts@aol.com BMJ 1998;317:1687

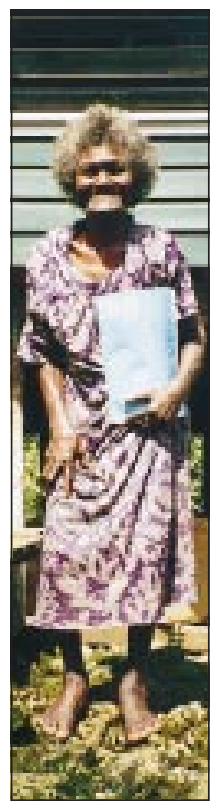

